\title{
Pengaruh geogebra online berbasis scaffolding dan tingkat self-regulated learning terhadap kemampuan berpikir kritis
}

Asih Miatun ${ }^{1 *}$ iD , Hikmatul Khusna ${ }^{1}$ (iD

${ }^{1}$ Department of Mathematics Education, Universitas Muhammadiyah Prof. Dr. Hamka, Jakarta, Indonesia

* Corresponding Author. E-mail: asihmiatun@uhamka.ac.id

\begin{tabular}{|c|c|}
\hline ARTICLE INFO & ABSTRACT \\
\hline $\begin{array}{l}\text { Article History: } \\
\text { Received: } 16 \text { Sept. } 2020 \\
\text { Revised: } 04 \text { Oct. } 2020 \\
\text { Accepted: } 28 \text { Dec. } 2020 \\
\text { Keywords: } \\
\text { Kemampuan berpikir kritis, } \\
\text { Critical Thinking Skills, } \\
\text { Self-regulated learning, } \\
\text { Geogebra, } \\
\text { Scaffolding. }\end{array}$ & $\begin{array}{l}\text { Penelitian ini bertujuan untuk menguji (1) pengaruh pembelajaran menggunakan Google Meet } \\
\text { dengan Geogebra online berbasis scaffolding terhadap kemampuan berpikir kritis mahasiswa; } \\
\text { (2) pengaruh tingkat Self-Regulated Learning (SRL) pada kemampuan berpikir kritis mahasiswa; } \\
\text { dan (3) pengaruh interaksi antara jenis pembelajaran dan tingkat SRL terhadap kemampuan } \\
\text { berpikir kritis mahasiswa. Desain penelitian yang digunakan adalah quasi-experiment. Sampel } \\
\text { penelitian adalah mahasiswa pendidikan matematika yang dipilih menggunakan teknik cluster } \\
\text { random sampling. Kelompok eksperimen ( } n=23 \text { ) diberi pembelajaran menggunakan Google } \\
\text { Meet dengan Geogebra online berbasis scaffolding, sedangkan kelompok kontrol ( } n=23 \text { ) diberi } \\
\text { pembelajaran menggunakan Google Meet tanpa bantuan Geogebra online. Pengumpulan data } \\
\text { menggunakan tes kemampuan berpikir kritis dan angket SRL. Teknik analisis data menggunakan } \\
\text { ANOVA dua jalan pada taraf signifikansi } 5 \% \text {. Hasil penelitian menunjukkan bahwa (1) kemam- } \\
\text { puan berpikir kritis kelompok yang diberi pembelajaran menggunakan Google Meet dengan } \\
\text { Geogebra online berbasis scaffolding lebih baik dibandingkan dengan kelompok kontrol; }(2) \\
\text { terdapat perbedaan signifikan kemampuan berpikir kritis mahasiswa ditinjau dari tingkat SRL, } \\
\text { dimana mahasiswa dengan SRL tinggi memiliki kemampuan berpikir kritis yang lebih baik } \\
\text { daripada mahasiswa dengan SRL sedang dan rendah, serta mahasiswa dengan SRL sedang } \\
\text { memiliki kemampuan berpikir kritis yang lebih baik daripada mahasiswa dengan SRL rendah; } \\
\text { dan (3) tidak terdapat pengaruh interaksi antara jenis pembelajaran dan tingkat SRL terhadap } \\
\text { kemampuan berpikir kritis mahasiswa. }\end{array}$ \\
\hline
\end{tabular}

Scan me:

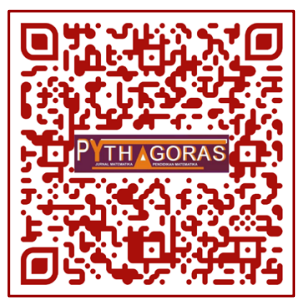

This study aimed to examine (1) the effect of learning using Google Meet with Geogebra online based on scaffolding on students' critical thinking skills; (2) the effect of the level of Self-Regulated Learning (SRL) on students' critical thinking skills; and (3) the effect of the interaction between the type of learning and the SRL level on students' critical thinking skills. The research design used was a quasi-experiment. The research sample was mathematics education students who were selected using the cluster random sampling technique. The experimental group $(n=23)$ was given learning using Google Meet with Geogebra online based on scaffolding, while the control group ( $n=23$ ) was given learning using Google Meet without the assistance of Geogebra online. Data collection used a critical thinking skills test and an SRL questionnaire. The data analysis technique used two-way ANOVA at a significance level of 5\%. The results showed that (1) the critical thinking ability of the group given learning using Google Meet with Geogebra online based on scaffolding was better than the control group; (2) there was a significant difference in students' critical thinking skills in terms of SRL level, where students with high SRL had better critical thinking skills than students with moderate and low SRL, and students with moderate SRL had better critical thinking skills than students with low SRL; and (3) there was no effect of the interaction between the type of learning and the SRL level on students' critical thinking skills.

This is an open access article under the CC-BY-SA license

\section{How to Cite:}

Miatun, A., \& Khusna, H. (2020 Pengaruh geogebra online berbasis scaffolding dan tingkat self-regulated learning terhadap kemampuan berpikir kritis. Pythagoras: Jurnal Pendidikan Matematika, 15(2), 124-136. https://doi.org/10.21831/pg.v15i2.34499 


\section{PENDAHULUAN}

Literasi matematis dan kemampuan berpikir kritis memiliki peran yang sangat penting dalam menghadapi abad 21 ini (Riyadhotul et al., 2019). Namun tuntutan ini berbanding terbalik dengan hasil PISA tahun 2018 yang menunjukkan bahwa kemampuan matematis siswa di Indonesia masih jauh di bawah negara lain, dimana Indonesia berada pada peringkat 74 dari 79 negara (OECD, 2019). Hasil ini menjelaskan bahwa kemampuan matematis siswa di Indonesia masih sangat rendah. Hal ini tentu menjadi catatan bagi lembaga pendidikan yang menghasilkan lulusan guru untuk menyelidiki kesiapan kemampuan matematis mahasiswa calon guru. Salah satu kemampuan matematis tersebut adalah kemampuan berpikir kritis.

Pendidikan matematika saat ini masuk pada era reformasi dimana pembelajaran tidak lagi menekankan pada pembelajaran kognitif algoritmik, tetapi bergeser pada penekanan kemampuan kognitif tingkat tinggi, salah satunya adalah kemampuan berpikir kritis (Aizikovitsh-Udi \& Amit, 2011; Aizikovitsh-Udi \& Cheng, 2015). Sejalan dengan itu, Sulistiani dan Masrukan (2017) menyebutkan bahwa high order thinking skill, yang salah satunya kemampuan berpikir kritis, merupakan salah satu alat dalam pembelajaran untuk membentuk SDM yang berkualitas. Kemampuan berpikir kritis menjadi penting untuk di kembangkan dalam pendidikan, karena dalam pembelajaran pemecahan masalah membutuhkan kemampuan berpikir kritis yang baik (Maričić \& Špijunović, 2015; Peter, 2012). Pembelajaran di sekolah saat ini diharapkan dapat mengembangkan kemampuan berpikir kritis. Salah satu calon pengembang kemampuan berpikir kritis di masa mendatang adalah mahasiswa, sehingga kemampuan berpikir kritis adalah salah satu kemampuan matematis yang wajib dimiliki oleh lulusan calon guru pendidikan matematika (Jacob, 2012). Chukwuyenum (2013) mengemukakan bahwa kemampuan berpikir kritis wajib ada dalam kurikulum pendidikan guru. Berdasarkan beberapa pendapat tersebut, terlihat bahwa kemampuan berpikir kritis merupakan salah satu kemampuan yang wajib dimiliki oleh calon guru matematika.

Berpikir kritis merupakan kemampuan kompleks yang melibatkan disposisi afektif dan kemampuan kognitif yang mempengaruhi bagaimana kemampuan penguasaan konsep matematis (Chukwuyenum, 2013). Kemampuan berpikir kritis jika ditingkatkan dengan baik dapat mendorong dan meningkatkan prestasi belajar (Jacob, 2012; Maričić \& Špijunović, 2015). Selain itu, kemampuan berpikir kritis memberikan pengaruh positif bagi peningkatan prestasi akademik mahasiswa (Fong et al., 2017). Mahasiswa merupakan calon guru yang nantinya memiliki tugas untuk mengembangkan kemampuan berpikir kritis siswa. Calon pendidik harus fokus dalam meningkatkan kemampuan berpikir tingkat tinggi, di antaranya adalah kemampuan berpikir kritis. Jika hal tersebut dilatihkan dari waktu ke waktu, lebih dimungkinkan akan berhasil meningkatkan kemampuan berpikir kritis (Aizikovitsh-Udi \& Amit, 2011).

Dari beberapa penelitian terdahulu, dilaporkan bahwa kemampuan berpikir kritis mahasiswa calon guru matematika masih rendah. Sebagian besar calon guru matematika hanya menguasai satu indikator kemampuan berpikir kritis yaitu mengatur strategi dan taktik (Miatun \& Khusna, 2020). Sejalan dengan hasil penelitian yang dilakukan Susilo et al. (2019) yang menyebutkan bahwa kemampuan berpikir kritis mahasiswa masih rendah pada bagian menentukan strategi penyelesaian masalah. Selain itu, mahasiswa juga merasa terhambat dalam memecahkan masalah karena kurangnya kemampuan berpikir kritis (Bailin, 2002; Rochmad et al., 2018). Sebaliknya, kemampuan pemecahan masalah juga mempengaruhi kemampuan berpikir kritis seseorang. Nursyahidah dan Albab (2018) menyebutkan bahwa mahasiswa dengan kemampuan pemecahan masalah level rendah juga memiliki kemampuan berpikir kritis yang rendah. Sedangkan hasil penelitian dari Incikabi et al. (2013) juga melaporkan bahwa kemampuan berpikir kritis mahasiswa calon guru matematika masih perlu ditingkatkan. Dengan demikian, perlu adanya upaya untuk meningkatkan kemampuan berpikir kritis mahasiswa calon guru

Kemampuan berpikir kritis mahasiswa calon guru dapat meningkat dengan proses pembelajaran yang berbasis pemecahan masalah konseptual (Cherubini, 2009). Lembaga pendidikan perlu mereformasi kurikulum pembelajarannya untuk meningkatkan dan mengembangkan kemampuan berpikir kritis bagi mahasiswa calon guru (As'ari et al., 2017). Rencana pembelajaran harus menekankan bagaimana siswa dapat memperoleh pengalaman belajar secara maksimal. Melibatkan pengalaman belajar secara aktif, baik secara akademis maupun non akademis agar mahasiswa dapat meningkatkan kemampuan berpikir kritisnya. Selain itu, pembelajaran yang lebih menekankan aspek instruksional juga memberikan pengaruh positif bagi peningkatan kemampuan berpikir kritis (Terenzini et al., 1995). Beberapa penelitian telah melaporkan bahwa terdapat beberapa model atau strategi pembelajaran menarik yang dapat meningkatkan kemampuan berpikir kritis. Kelas eksperimen yang menggunakan bahan ajar yang dipersiapkan secara khusus untuk kemampuan berpikir kritis dilaporkan dapat meningkatkan kemampuan 
berpikir kritis (Aizikovitsh \& Amit, 2010; Chukwuyenum, 2013). Penerapan model pembelajaran berbasis pendekatan kognitif juga dapat meningkatkan kemampuan berpikir kritis (Vong \& Kaewurai, 2017). Dengan demikian, kemampuan berpikir kritis dapat dikembangkan dengan penerapan pendekatan, model, atau strategi pembelajaran yang tepat. Berbagai alternatif pembelajaran yang dapat dimanfaatkan untuk meningkatkan kemampuan berpikir kritis, salah satunya adalah scaffolding (Kurniasih, 2012).

Scaffolding adalah salah satu metode yang dapat digunakan untuk meningkatkan kemampuan berpikir kritis (Browne et al., 2009; Kim et al., 2013), meningkatkan keterampilan matematis (Barzilai \& Blau, 2014), mengembangkan proses berpikir (Moschkovich, 2015), dan memberikan dampak terhadap kemandirian belajar (Smit et al., 2013). Hasil penelitian dari Sunaryo dan Fatimah (2019) menyebutkan bahwa pembelajaran dengan menggunakan scaffolding dapat meningkatkan kemampuan berpikir kritis jika dibandingkan dengan pembelajaran kontekstual. Hal ini sejalan dengan hasil penelitian Devolder et al. (2012) yang memberikan hasil bahwa scaffolding memberikan pengaruh yang signifikan terhadap pembelajaran. Wood et al. (Bakker et al., 2015) menyebutkan bahwa scaffolding pada dasarnya adalah suatu pembelajaran dimana guru memberikan bantuan atau bimbingan kepada siswa dan semakin lama mengurangi bantuan tersebut sampai siswa bisa "berdiri sendiri". Roehler dan Cantlon (Bikmaz et al., 2010) menyebutkan bahwa terdapat lima teknik yang biasa digunakan dalam scaffolding dalam pembelajaran yaitu memberikan penjelasan (offering explanations), mengajak siswa berpartisipasi (inviting student participation), verifikasi dan klarifikasi pemahaman siswa terhadap materi (verifying and clarifying student understandings), memodelkan perilaku tertentu dalam belajar (modeling of desired behaviors), dan mengajak siswa memberikan petunjuk dalam menyelesaikan permasalahan (inviting students to contribute clues). Melalui teknikteknik tersebut diharapkan permasalahan pembelajaran dapat diatasi.

Penelitian ini dilaksanakan ketika masa pandemi COVID-19. Pada masa pandemi ini pembelajaran tatap muka diganti dengan pembelajaran daring menggunakan media Google Meet. Pembelajaran menggunakan Google Meet ini akan dipadukan dengan aplikasi Geogebra online berbasis scaffolding. Zengin (2017) menyebutkan bahwa dengan menggunakan Geogebra dapat meningkatkan kemampuan pembuktian matematis. Dengan menggunakan Geogebra online dapat membantu siswa untuk memvisualisasikan proses matematika secara memadai (Dikovic, 2009). Pada mata kuliah geometri yang dilaksanakan secara online, mahasiswa sering mengeluhkan tentang sulitnya memahami materi jika hanya melihat visualisasi dari buku saja. Geogebra online merupakan salah satu media yang cukup interaktif untuk digunakan dalam pembelajaran matematika (Velichová, 2011). Ekawati (2016) juga menyebutkan bahwa Geogebra dapat melatih daya kreatif dan daya kritis. Selain itu, hasil penelitian Shadaan dan Eu (2013) menunjukkan bahwa kelas yang menggunakan Geogebra menunjukkan perbedaan ratarata prestasi belajar yang signifikan jika dibandingkan dengan kelas yang tidak menggunakan Geogebra.

Selain kemampuan kognitif, kemampuan afektif yang baik juga harus dimiliki mahasiswa. Self Regulated Learning (SRL) masuk ke dalam ranah afektif pada pembelajaran matematika. SRL erat hubungannya dengan kemandirian belajar (Sumarmo, 2002). SRL merupakan suatu proses yang dapat membantu siswa dalam mengelola emosi, pikiran, dan perilaku agar berhasil mengelola pengalaman belajar yang diperoleh (Zimmerman \& Martinez-Pons, 1988; Zumbrunn et al., 2011). Proses ini terjadi ketika perilaku siswa dan proses belajar yang dilakukan diarahkan untuk memperoleh informasi dan keterampilan. Hasil penelitian Kramarski dan Revach (2009) menyebutkan bahwa SRL memiliki hubungan dengan kemampuan kognitif dalam matematika. Hal ini sejalan dengan hasil penelitian Darr dan Fisher (2005) yang menunjukkan bahwa SRL yang dimiliki oleh siswa dapat digunakan untuk memberi pilihan dan menyusun strategi dalam penyelesaian masalah matematika. Dimana penyusunan strategi berhubungan dengan kemampuan berpikir kritis.

Vrieling et al. ( 2018) menyebutkan bahwa keterampilan SRL sangat dibutuhkan oleh calon guru. SRL yang dimiliki oleh individu dapat dimanfaatkan secara maksimal pada saat pembelajaran berbasis scaffolding (Perry et al., 2008). Shih et al. (2010) menyebutkan bahwa SRL dan scaffolding dapat mendukung pembelajaran yang dilaksanakan secara online. Pembelajaran yang dilaksanakan secara online sangat membutuhkan pengaturan diri dalam belajar, sehingga penyerapan ilmu menjadi maksimal. Selain itu, SRL juga memiliki hubungan dengan kemampuan berpikir kritis. Ghanizadeh (2011) menyebutkan bahwa SRL memiliki korelasi yang tinggi dengan komponen berpikir kritis membuat kesimpulan (interpretasi) dan memberikan penjelasan atau argumen lebih lanjut terhadap jawaban yang diberikan. Selain itu, hasil penelitian dari Hidayati dan Kurniati, (2018) melaporkan bahwa terdapat pengaruh SRL terhadap kemampuan berpikir kritis pada kelas yang menggunakan Geogebra pada pembelajarannya yaitu sebesar $47,5 \%$. 
Mengingat perlunya kemampuan berpikir kritis untuk dikuasai mahasiswa calon guru, maka perlu adanya suatu upaya untuk meningkatkan kemampuan berpikir kritis. Upaya yang dimaksud adalah dengan menerapkan scaffolding. Namun ketika pandemi COVID-19, pembelajaran harus dilaksanakan secara online. Agar penerapan scaffolding tersebut maksimal maka digunakan Geogebra online sebagai sistem manajemen pembelajarannya. Selain itu, kemampuan berpikir kritis juga dimungkinkan dipengaruhi oleh aspek afektif yaitu SRL. Dengan demikian, penelitian ini bertujuan untuk menyelidiki pengaruh penggunaan Geogebra online berbasis scaffolding dan tingkat SRL terhadap kemampuan berpikir kritis mahasiswa. Lebih rincinya, tujuan penelitian ini adalah untuk menguji (1) pengaruh pembelajaran menggunakan Google Meet dengan Geogebra online berbasis scaffolding terhadap kemampuan berpikir kritis mahasiswa; (2) pengaruh tingkat SRL pada kemampuan berpikir kritis mahasiswa; dan (3) pengaruh interaksi antara jenis pembelajaran dan tingkat SRL terhadap kemampuan berpikir kritis mahasiswa.

\section{METODE}

Jenis penelitian yang dilakukan adalah penelitian quasi-experiment. Penelitian ini dilaksanakan pada semester genap tahun ajaran 2019/2020 di Program Studi Pendidikan Matematika Universitas Muhammadiyah Prof. Dr. Hamka (UHAMKA). Populasi pada penelitian ini adalah mahasiswa semester genap di program studi pendidikan matematika, Fakultas Keguruan dan IImu Pendidikan, UHAMKA. Teknik pengambilan sampel pada penelitian ini menggunakan cluster random sampling. Instrumen utama untuk pengambilan data dalam penelitian ini adalah tes kemampuan berpikir kritis dan angket SRL yang sebelumnya telah divalidasi oleh ahli.

Tes kemampuan berpikir kritis terdiri dari lima soal uraian dengan indikator yang diadaptasi dari Ennis (1985). Indikator-indikator tersebut meliputi: (1) memberi penjelasan dasar/sederhana; (2) membangun keterampilan dasar; (3) menyusun kesimpulan; (4) memberi penjelasan lebih lanjut; dan (5) menyusun strategi dan taktik. Angket SRL terdiri dari 50 pernyataan dengan lima pilihan jawaban yaitu: Sangat Setuju, Setuju, Netral, Tidak Setuju, dan Sangat Tidak Setuju. Angket SRL ini disusun berdasarkan aspek yang dikembangkan oleh Zimmerman dan Martinez-Ponz (1990) yaitu: (1) personal function, dengan indikator menetapkan tujuan dan membuat perencanaan (goal setting and planning), berlatih dan menghafal (rehearsing and memorizing); (2) behavioral function, dengan indikator mengevaluasi diri (self-evaluating), dan konsekuensi diri (self-consequenting); dan (3) environmental function, dengan indikator mencari informasi (seeking information), membuat catatan dan mengamati diri (keeping records and self-monitoring), menyusun lingkungan (environmental structuring), dan mencari bantuan (seeking social assistance).

Angket SRL diberikan sebelum perlakuan dengan media pengisian Google Form. Selanjutnya berdasarkan skor hasil pengisian angket, SRL sampel akan dikategorikan menjadi tinggi, sedang, dan rendah. Setelah diberikan angket, kedua kelompok sampel diberi perlakuan pembelajaran daring menggunakan aplikasi Google Meet. Kelas pertama pembelajaran dilakukan berbantuan Geogebra online berbasis scaffolding yang selanjutnya disebut sebagai kelas eksperimen $(n=23)$. Kelas kedua dilangsungkan pembelajaran dengan Google Meet tanpa bantuan Geogebra online yang selanjutnya disebut sebagai kelas kontrol $(n=23)$. Sedangkan untuk tes kemampuan berpikir kritis dilaksanakan juga secara online dengan metode mengeluarkan soal satu persatu dan setiap soal memiliki waktu pengerjaan. Hal ini dilakukan untuk mengantisipasi adanya kecurangan pada saat mengerjakan tes.

Tabel 1. Rancangan penelitian

\begin{tabular}{|c|c|c|c|c|}
\hline Perlakuan (a) & Tingkat SRL $(b)$ & Tinggi $\left(b_{1}\right)$ & Sedang $\left(b_{2}\right)$ & Rendah $\left(b_{3}\right)$ \\
\hline $\begin{array}{l}\text { Eksperimen }\left(a_{1}\right) \\
\text { Kontrol }\left(a_{2}\right)\end{array}$ & & $\begin{array}{l}(a b)_{11} \\
(a b)_{21}\end{array}$ & $\begin{array}{l}(a b)_{12} \\
(a b)_{22}\end{array}$ & $\begin{array}{l}(a b)_{13} \\
(a b)_{23}\end{array}$ \\
\hline
\end{tabular}

Penelitian ini menggunakan rancangan desain faktorial $2 \times 3$ yang dijelaskan seperti pada Tabel 1 . Sel $(a b)_{11}$ berisi data kemampuan berpikir kritis yang diberikan pada kelas eksperimen dan sampel mempunyai SRL tinggi, sel $(a b)_{21}$ berisi data kemampuan berpikir kritis yang diberikan pada kelas kontrol dan sampel mempunyai SRL tinggi, dan seterusnya. Kelas eksperimen pada penelitian ini menggunakan Google Meet dengan Geogebra online berbasis scaffolding dengan sampel sebanyak 23 mahasiswa, sedangkan kelas kontrolnya menggunakan Google Meet tanpa Geogebra online dengan sampel sebanyak 23 mahasiswa. Kedua kelas menggunakan Google Meet sebagai pengganti pertemuan tatap muka karena penelitian dilaksanakan ketika pandemi COVID-19. 
Sebelum hipotesis penelitian diuji, dilakukan uji prasyarat analisis yaitu: (1) uji normalitas pada tiap kolom dan baris menggunakan uji Lilifors; (2) uji homogenitas untuk kelompok sampel menggunakan metode Bartlett dengan statistik uji Chi Kuadrat. Sebelum diberi perlakuan, dilakukan uji keseimbangan pada kelas eksperimen dan kontrol. Uji keseimbangan menggunakan ANOVA satu arah dengan sel sama. Uji ini dilakukan untuk mengetahui apakah kedua kelompok sampel berasal dari populasi dengan kemampuan awal yang sama atau tidak.

Analisis data setelah perlakuan menggunakan ANOVA dua arah dengan sel tak sama. Sel tak sama merujuk pada banyaknya sampel masing-masing sel yang tidak sama. Pada penelitian ini terdapat tiga hipotesis yang akan diuji, yaitu:

\section{Hipotesis 1:}

$H_{0}$ : Tidak terdapat perbedaan kemampuan berpikir kritis antar perlakuan

$H_{1}$ : Terdapat perbedaan kemampuan berpikir kritis antar perlakuan

\section{Hipotesis 2:}

$H_{0}$ : Tidak terdapat perbedaan kemampuan berpikir kritis antar level SRL

$H_{1}$ : Terdapat minimal satu perbedaan kemampuan berpikir kritis antar level SRL

\section{Hipotesis 3:}

$H_{0}$ : Tidak terdapat pengaruh interaksi antara perlakuan dengan level SRL terhadap kemampuan berpikir kritis $H_{1}$ : Terdapat pengaruh interaksi antara perlakuan dengan level SRL terhadap kemampuan berpikir kritis

Jika pada pengujian $H_{0}$ ditolak, maka akan dilakukan uji lanjut pasca ANOVA menggunakan metode Scheffe. Uji ini dilakukan untuk melihat perbedaan rerata setiap pasangan interaksi, klasifikasi faktor, dan setiap pasangan sel. Semua pengujian statistik dilakukan pada taraf signifikansi $5 \%(\alpha=0,05)$.

\section{HASIL PENELITIAN}

\section{Deskripsi Kemampuan Awal}

Sebelum diberikan perlakuan, perlu diuji keseimbangan antara dua kelompok sampel. Uji keseimbangan ini bertujuan untuk mendapatkan info apakah kedua kelompok memiliki kemampuan awal yang sama. Data yang digunakan untuk uji kemampuan awal adalah data nilai Ujian Tengah Semester (UTS). Tabel 2 menyajikan deskripsi data kemampuan awal dua kelompok sampel yang akan diuji.

Tabel 2. Deskripsi data kemampuan awal mahasiswa

\begin{tabular}{lccccc}
\hline Kelompok & $n$ & Nilai minimum & Nilai maksimum & Mean & Simpangan baku \\
\hline Eksperimen & 23 & 44 & 84 & 70,26 & 9,77 \\
Kontrol & 23 & 39 & 91 & 69.86 & 10,88 \\
\hline
\end{tabular}

Uji keseimbangan menggunakan ANOVA satu jalan dengan sel sama. Sebelum di uji keseimbangan reratanya, data harus memenuhi syarat normal dan homogen terlebih dahulu. Hipotesis yang digunakan dalam uji normalitas adalah $H_{0}$ : sampel berasal dari populasi yang berdistribusi normal, dan $H_{1}$ : sampel tidak berasal dari populasi yang berdistribusi normal. Hasil uji normalitas untuk dua kelompok sampel disajikan pada Tabel 3.

Tabel 3. Hasil uji normalitas kemampuan awal

\begin{tabular}{lcccc}
\hline Kelompok & $L_{\text {obs }}$ & $L_{\text {tabel }}$ & Keputusan & Kesimpulan \\
\hline Eksperimen & 0,1258 & 0,1847 & $H_{0}$ diterima & Normal \\
Kontrol & 0,0799 & 0,1847 & $H_{0}$ diterima & Normal \\
\hline
\end{tabular}

$L_{\text {obs }}$ merupakan koefisien Liliefors dari data setiap kelompok sampel, sedangkan $L_{\text {tabel }}$ merupakan koefisien yang diperoleh dari tabel Liliefors. Berdasarkan Tabel 3 terlihat bahwa $L_{o b s}$ kelompok eksperimen dan kontrol kurang dari $L_{\text {tabel }}$, sehingga pada taraf signifikansi 0,05 hipotesis nol kedua kelompok diterima. Dengan demikian, dapat disimpulkan bahwa kedua kelompok sampel berasal dari populasi yang berdistribusi normal. Selanjutnya dilakukan uji homogenitas dengan hipotesis yaitu $H_{0}$ : variansi sama (kedua sampel berasal dari populasi dengan variansi yang homogen) dan $H_{1}$ : tidak semua variansi sama (kedua sampel berasal dari populasi dengan variansi yang tidak 
homogen). Hasil uji homogenitas kemampuan awal dua kelompok sampel diperoleh $\chi^{2}{ }_{o b s}=0,2526$ dengan daerah kritis $D K=\left\{\chi^{2} \mid \chi^{2}>\chi^{2}{ }_{0,05 ; 2-1}\right\}=\left\{\chi^{2} \mid \chi^{2}>3,841\right\}$. Dari hasil uji homogenitas diperoleh bahwa $\chi^{2}{ }_{\text {obs }} \notin D K$ maka hipotesis nol diterima. Dengan demikian, dapat disimpulkan bahwa kedua kelompok sampel berasal dari populasi yang memiliki variansi sama.

Selanjutnya data kemampuan awal diuji keseimbangannya menggunakan ANOVA satu jalan dengan sel sama. Hipotesis yang diuji yaitu $H_{0}$ : rerata kemampuan awal mahasiswa pada kelompok eksperimen dan kelompok kontrol adalah sama, dan $H_{1}$ : rerata kemampuan awal mahasiswa pada kelompok eksperimen dan kelompok kontrol tidak sama. Hasil pengujian memperoleh hasil $F_{o b s}=0,016$ dengan daerah kritis $D K=\{F \mid F>$ $4,062\}$. Karena $F_{\text {obs }} \notin D K$ sehingga hipotesis nol diterima dan disimpulkan bahwa kedua kelompok sampel berasal dari populasi dengan rerata kemampuan awal yang seimbang. Selanjutnya kedua kelompok sampel dapat diberikan perlakuan berbeda dan dibandingkan.

\section{Deskripsi Self-Regulated Learning Mahasiswa}

Sebelum kelompok eksperimen diberikan perlakuan yaitu pembelajaran menggunakan Geogebra online berbasis scaffolding, sampel diberikan angket SRL terlebih dahulu. Selanjutnya data hasil pengisian dikelompokkan menjadi tiga kategori, tinggi, sedang dan rendah. Pengkategorian tersebut berdasarkan pada rerata $(\bar{X})$ dan setengah dari standar deviasi $(0,5 s)$ (Budiyono, 2011). Dari perhitungan diperoleh $\bar{X}=187,5$ dan $s=7,773$, sehingga diperoleh kategori SRL siswa seperti disajikan pada Tabel 4.

Tabel 4. Kategori SRL mahasiswa

\begin{tabular}{lcc}
\hline Kategori & Interval & Interval skor \\
\hline Tinggi & $X>\bar{X}+0,5 s$ & $X>195,27$ \\
Sedang & $\bar{X}-0,5 s \leq X \leq \bar{X}+0,5 s$ & $179,73 \leq X \leq 195,27$ \\
Rendah & $X<\bar{X}-0,5 s$ & $X<179,73$ \\
\hline
\end{tabular}

Dari Tabel 4 mahasiswa memiliki SRL kategori tinggi apabila skor angket lebih dari 195,27, SRL kategori sedang apabila skor angketnya berada pada interval 179,73 sampai 195,27, dan termasuk SRL kategori rendah jika skor angketnya kurang dari 179,73. Sebaran kategori SRL mahasiswa berdasarkan kategorisasi tersebut disajikan pada Tabel 5.

Tabel 5. Sebaran kategori SRL mahasiswa

\begin{tabular}{lcccc}
\hline \multirow{2}{*}{ Kelompok } & \multicolumn{3}{c}{ Banyak siswa untuk masing-masing kategori SRL } & \multirow{2}{*}{ Total } \\
\cline { 2 - 4 } & Tinggi & Sedang & Rendah & \\
\hline Eksperimen & 6 & 11 & 6 & 23 \\
Kontrol & 7 & 8 & 8 & 23 \\
Total & 13 & 19 & 14 & \\
\hline
\end{tabular}

\section{Pengujian Hipotesis}

Hasil tes kemampuan berpikir kritis ini selanjutnya akan digunakan untuk uji hipotesis penelitian. Uji hipotesis penelitian menggunakan ANOVA dua jalan dengan sel tak sama dan uji lanjut menggunakan metode Scheffe. Sebelum dilakukan uji hipotesis, dilakukan uji normalitas data dan uji homogenitas. Uji normalitas menggunakan metode Lilliefors dengan taraf signifikansi 0,05. Tabel 6 merupakan rangkuman hasil uji normalitas data tes kemampuan berpikir kritis.

Tabel 6. Rangkuman hasil uji normalitas data kemampuan berpikir kritis

\begin{tabular}{lcccc}
\hline Kelompok data & $L_{\text {obs }}$ & $L_{\text {tabel }}$ & Keputusan & Kesimpulan \\
\hline Eksperimen & 0,099 & 0,185 & $H_{0}$ diterima & Normal \\
Kontrol & 0,102 & 0,185 & $H_{0}$ diterima & Normal \\
SRL tinggi & 0,204 & 0,246 & $H_{0}$ diterima & Normal \\
SRL sedang & 0,118 & 0,203 & $H_{0}$ diterima & Normal \\
SRL rendah & 0,159 & 0,237 & $H_{0}$ diterima & Normal \\
\hline
\end{tabular}


Berdasarkan Tabel 6 dapat dilihat bahwa $L_{o b s}$ untuk masing-masing kelompok kurang dari $L_{\text {tabel }}$, sehingga $H_{0}$ diterima. Hal ini berarti masing-masing kelompok data berasal dari populasi yang berdistribusi normal.

Uji homogenitas data kemampuan berpikir kritis yang dilakukan yaitu: (1) uji homogenitas antar baris perlakukan pada kelompok eksperimen dan kontrol; dan (2) uji homogenitas antar kolom pada kategori SRL tinggi, sedang, dan rendah. Tabel 7 menyajikan rangkuman hasil uji homogenitas data kemampuan berpikir kritis.

Tabel 7. Rangkuman hasil uji homogenitas kemampuan berpikir kritis

\begin{tabular}{lcccc}
\hline Kelompok & $\chi^{2}{ }_{\text {obs }}$ & $\chi^{2}$ tabel & Keputusan & Kesimpulan \\
\hline Perlakuan (eksperimen dan kontrol) & 1,983 & 3,841 & $H_{o}$ diterima & Homogen \\
SRL (tinggi, sedang, dan rendah) & 0,509 & 5,991 & $H_{o}$ diterima & Homogen \\
\hline
\end{tabular}

Berdasarkan Tabel 7, terlihat bahwa $\chi^{2}{ }_{\text {obs }}$ pada masing-masing kelompok kurang dari $\chi^{2}{ }_{\text {tabel }}$ sehingga $H_{0}$ diterima. Dengan demikian, dapat disimpulkan bahwa populasi sampel yang diberi perlakuan pada kelas eksperimen dan kontrol, serta populasi kelompok yang mempunyai SRL tinggi, sedang, dan rendah mempunyai variansi populasi yang sama (homogen).

Berdasarkan uji prasyarat, sampel memenuhi uji prasyarat analisis variansi dua jalan dengan sel tak sama yaitu sampel berasal dari populasi yang berdistribusi normal dan sampel memiliki variansi yang sama. Pengujian menggunakan ANOVA dua jalan dengan sel tak sama dilakukan untuk mengetahui apakah terdapat perbedaan pengaruh antara perlakuan, tingkat SRL, dan interaksinya terhadap kemampuan berpikir kritis. Tabel 8 menyajikan rangkuman hasil perhitungan ANOVA dua jalan dengan sel tak sama.

Tabel 8. Hasil uji ANOVA

\begin{tabular}{lrrrrrl}
\hline Sumber & $J K$ & $d f$ & $R K$ & $F_{\text {obs }}$ & $F_{\text {tabel }}$ & Keputusan \\
\hline Perlakuan (A) & 553,654 & 1 & 553,654 & 6,922 & 4,085 & $H_{0}$ ditolak \\
SRL (B) & 7522,825 & 2 & 3761,413 & 47,027 & 3,232 & $H_{0}$ ditolak \\
Interaksi (AB) & 53,795 & 2 & 26,897 & 0,336 & 3,232 & $H_{0}$ diterima \\
Galat (G) & 3199,373 & 40 & 79,984 & & & \\
Total & 11329,648 & 45 & & & & \\
\hline
\end{tabular}

Berdasarkan Tabel 8, terlihat bahwa pada efek utama perlakuan (A), diperoleh $F_{o b s}=6,922$ dengan daerah kritis $D K=\left\{F \mid F>F_{0,05: 1,40}\right\}=\{F \mid F>4,085\}$, karena $F_{\text {obs }}$ berada pada daerah kritis, maka $H_{0}$ ditolak. Hal ini menunjukkan bahwa terdapat perbedaan kemampuan berpikir kritis antara kelompok eksperimen dan kelompok kontrol; Pada efek utama SRL (B), diperoleh $F_{o b s}=47,027$ dengan daerah kritis $D K=\left\{F \mid F>F_{0,05: 2,40}\right\}=$ $\{F \mid F>3,323\}$, karena $F_{o b s}$ berada pada daerah kritis, maka $H_{0}$ ditolak. Hal ini berarti bahwa terdapat perbedaan kemampuan berpikir kritis ditinjau dari kategori SRL (tinggi, sedang, dan rendah). Pada efek utama interaksi antara perlakuan dan SRL (AB), diperoleh $F_{o b s}=0,336$ dengan daerah kritis $D K=\left\{F \mid F>F_{0,05: 2,40}\right\}=$ $\{F \mid F>3,232\}$, karena $F_{o b s}$ berada di luar daerah kritis, maka $H_{0}$ diterima. Dengan demikian dapat disimpulkan bahwa tidak terdapat pengaruh interaksi antara perlakuan dan kategori SRL mahasiswa terhadap kemampuan berpikir kritis.

\section{Kemampuan Berpikir Kritis Ditinjau dari Jenis Perlakuan dan Kategori SRL}

Uji lanjut pasca ANOVA menggunakan uji komparasi ganda dengan metode Scheffe. Pada Tabel 9 disajikan rangkuman rerata antar sel lengkap dengan rerata marginalnya.

Tabel 9. Rerata kemampuan berpikir kritis berdasarkan jenis perlakuan dan kategori SRL

\begin{tabular}{lcccc}
\hline \multirow{2}{*}{ Perlakuan } & \multicolumn{3}{c}{ SRL } & \multirow{2}{*}{ Rerata Marginal } \\
\cline { 2 - 4 } & Tinggi & Sedang & Rendah & 66,26 \\
Eksperimen & 85,42 & 64,62 & 51,12 & 59,30 \\
Kontrol & 76,00 & 56,90 & 47,00 & \\
Rerata Marginal & 81,07 & 60,15 & 49,35 & \\
\hline
\end{tabular}


Dari hasil perhitungan uji ANOVA dua arah dengan sel tak sama pada Tabel 8, dapat disimpulkan bahwa terdapat perbedaan signifikan kemampuan berpikir kritis antara kelompok eksperimen dan kelompok kontrol. Berdasarkan Tabel 9 dapat dilihat bahwa rerata marginal kemampuan berpikir kritis kelas eksperimen sebesar 66,26, lebih tinggi dari rerata marginal kemampuan berpikir kritis kelompok kontrol yaitu sebesar 59,30. Ini berarti bahwa kemampuan berpikir kritis kelompok eksperimen yang berikan pembelajaran dengan Google Meet menggunakan Geogebra online berbasis scaffolding lebih baik daripada kelompok kontrol yang diberikan pembelajaran dengan Google Meet tanpa Geogebra online.

Hasil perhitungan uji ANOVA pada Tabel 8 juga menunjukkan terdapat perbedaan kemampuan berpikir kritis ditinjau dari masing-masing kategori SRL (tinggi, sedang, dan rendah). Tabel 10 menyajikan hasil uji lanjut pasca ANOVA untuk efek antar kolom.

Tabel 10. Rangkuman uji komparasi rerata kategori SRL

\begin{tabular}{lccc}
\hline Perbandingan & $F_{\text {obs }}$ & $F_{\text {tabel }}$ & Keputusan \\
\hline Tinggi vs. Sedang & 42,230 & 6,464 & $H_{0}$ Ditolak \\
Sedang vs. Rendah & 11,756 & 6,464 & $H_{0}$ Ditolak \\
Tinggi vs. Rendah & 84,794 & 6,464 & $H_{0}$ Ditolak \\
\hline
\end{tabular}

Berdasarkan uji komparasi rerata antar kolom yang dirangkum pada Tabel 10, dapat disimpulkan bahwa terdapat perbedaan kemampuan berpikir kritis pada mahasiswa dengan SRL tinggi dan mahasiswa dengan SRL sedang. Berdasarkan Tabel 9 diketahui bahwa rerata marginal mahasiswa dengan SRL tinggi sebesar 81,07, sedangkan rerata marginal mahasiswa dengan SRL sedang yaitu 60,15. Dengan demikian dapat disimpulkan bahwa mahasiswa dengan SRL tinggi memiliki kemampuan berpikir kritis yang lebih baik daripada mahasiswa dengan SRL sedang. Berdasarkan Tabel 10 juga dapat disimpulkan bahwa terdapat perbedaan kemampuan berpikir kritis antara mahasiswa dengan SRL sedang dan mahasiswa dengan SRL rendah. Mengacu pada Tabel 9, diketahui bahwa rerata marginal mahasiswa dengan SRL sedang sebesar 60,15, sedangkan rerata marginal mahasiswa dengan SRL rendah yaitu 49,35. Dengan demikian dapat disimpulkan bahwa mahasiswa dengan SRL sedang memiliki kemampuan berpikir kritis lebih baik daripada mahasiswa dengan SRL rendah. Selanjutnya, masih berdasarkan Tabel 10, dapat disimpulkan bahwa terdapat perbedaan kemampuan berpikir kritis antara mahasiswa dengan SRL tinggi dan mahasiswa dengan SRL rendah. Berdasarkan Tabel 9, diketahui bahwa rerata marginal mahasiswa dengan SRL tinggi sebesar 81,07, sedangkan rerata marginal mahasiswa dengan SRL rendah yaitu 49,35. Dengan demikian dapat disimpulkan bahwa kemampuan berpikir kritis mahasiswa dengan SRL tinggi lebih baik daripada mahasiswa dengan SRL rendah.

\section{PEMBAHASAN}

Hasil penelitian menunjukkan bahwa terdapat perbedaan kemampuan berpikir kritis antar perlakuan. Kelompok eksperimen yang menggunakan Google Meet dengan Geogebra online berbasis scaffolding mempunyai kemampuan berpikir kritis yang lebih baik dibandingkan dengan kelompok kontrol yang menggunakan Google Meet tanpa Geogebra online. Hal ini sejalan dengan beberapa hasil penelitian, misalnya Browne et al. (2009), Kurniasih (2012), dan Moschkovich (2015) yang menyebutkan bahwa scaffolding merupakan salah satu alternatif pembelajaran yang dapat meningkatkan kemampuan berpikir kritis. Selain itu, hasil penelitian Shadaan dan Eu (2013) juga menunjukkan bahwa kelas yang menggunakan Geogebra menunjukkan perbedaan rata-rata yang signifikan dibandingkan dengan kelas yang tidak menggunakan Geogebra.

Dengan menggunakan media Geogebra online berbasis scaffolding, mahasiswa diberikan suatu lembar kerja yang langsung dikerjakan secara online seperti pada Gambar 1. Dengan menggunakan Geogebra online penjelasan materi dapat disampaikan dengan jelas, mahasiswa juga dapat berpartisipasi secara aktif dalam menyelesaikan masalah karena melakukan praktik secara langsung, dan dengan menggunakan media Geogebra online mahasiswa dapat mencoba berkali-kali memecahkan masalah yang diberikan sampai diperoleh jawaban yang benar. Hal tersebut sejalan dengan teknik scaffolding yang dikemukakan oleh Roehler dan Cantlon (Bikmaz et al., 2010) yaitu memberi penjelasan, mengajak siswa berpartisipasi aktif, dan mengajak siswa mencari suatu petunjuk. 


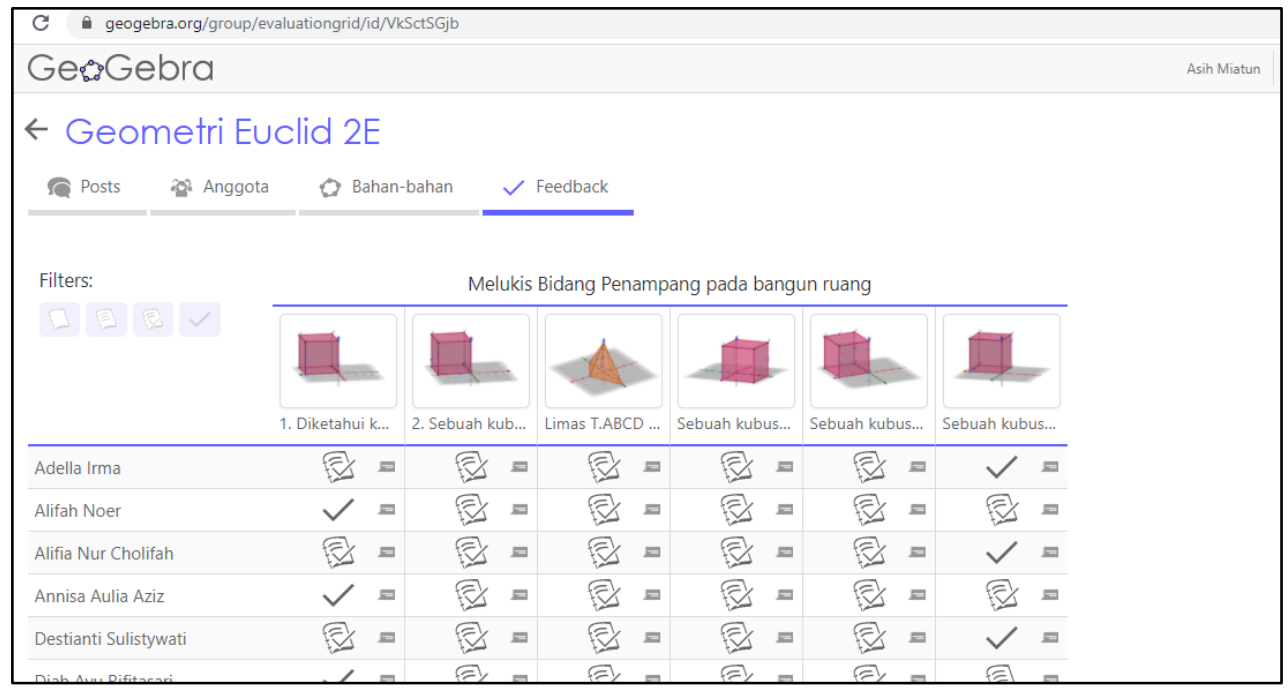

Gambar 1. Pembelajaran menggunakan Geogebra online

Pembelajaran yang berbeda dari biasanya dan lebih menarik menjadi salah satu faktor mengapa kemampuan berpikir kritis siswa menjadi lebih baik (Quitadamo et al., 2009). Selain itu, Geogebra online juga merupakan salah satu media yang dapat memfasilitasi mahasiswa untuk tetap aktif mengikuti proses belajar, sehingga menghasilkan interaksi dan pengalaman belajar yang bermakna. Interaksi maupun pengalaman belajar yang tersusun dan terencana dengan baik dapat meningkatkan kemampuan berpikir kritis (Peter, 2012; Terenzini et al., 1995).

Hasil penelitian juga menunjukkan bahwa mahasiswa dengan SRL tinggi memiliki kemampuan berpikir kritis yang lebih baik jika dibandingkan dengan mahasiswa dengan SRL sedang dan rendah. SRL sangat penting dimiliki karena berkaitan dengan kemampuan individu untuk mengatur dan memonitor dengan baik dirinya sendiri dalam proses belajar (Qohar \& Sumarmo, 2013). Selain itu individu yang memiliki SRL tinggi cenderung memiliki prestasi belajar yang lebih baik dan memiliki hubungan yang sangat erat dengan keterampilan kognitif dalam matematika (Kramarski \& Revach, 2009). Dimana kemampuan berpikir kritis merupakan salah satu keterampilan kognitif dalam matematika. Siswa dengan SRL tinggi mampu memilih dan menyusun strategi dalam penyelesaian masalah (Darr \& Fisher, 2005). Dalam hal ini kemampuan berpikir kritis merupakan salah satu kemampuan yang dibutuhkan dalam pemecahan masalah (Bailin, 2002). Hasil penelitian juga menunjukkan bahwa kemampuan berpikir kritis mahasiswa dengan SRL sedang lebih baik daripada mahasiswa dengan SRL rendah. Hal ini dikarenakan siswa dengan SRL sedang memiliki keterampilan mengatur dan menyusun kegiatan belajarnya dengan lebih baik jika dibandingkan dengan mahasiswa yang memiliki SRL rendah. Mahasiswa calon guru harus memiliki SRL yang baik, karena SRL merupakan salah satu alasan mengapa kemampuan kognitif individu dapat berkembang (Vrieling et al., 2018).

Kedua perlakuan dan SRL masing-masing memberikan perbedaan terhadap kemampuan berpikir kritis mahasiswa. Namun interaksi antara perlakuan dan SRL tidak memberikan pengaruh terhadap kemampuan berpikir kritis mahasiswa. Hal ini bertolak belakang dengan hasil penelitian Bell dan Pape (2014) yang menyebutkan bahwa scaffolding dan SRL saling berkaitan satu sama lain. Beberapa hasil penelitian memaparkan hubungan antara scaffolding dengan SRL (Perry et al., 2008), SRL dengan kemampuan berpikir kritis (Hidayati \& Kurniati, 2018), dan scaffolding dengan kemampuan berpikir kritis (Kim et al., 2013). Namun hasil penelitian-penelitian tersebut menunjukkan bahwa antar variabel memberikan hubungan yang positif. Selain itu, hasil penelitian Hidayati dan Kurniati (2018) juga menyebutkan bahwa terdapat pengaruh SRL terhadap kemampuan berpikir kritis pada kelas yang menggunakan Geogebra dalam pembelajarannya sebesar $47,5 \%$. Masih belum ditemukan penelitian yang membahas tentang Geogebra online berbasis scaffolding, SRL, dan kemampuan berpikir kritis secara bersamaan, serta pelaksanaan pembelajarannya secara online. Pelaksanaan pembelajaran secara online menggunakan Google Meet ini juga merupakan hal yang baru bagi sampel penelitian ini. Hal ini dimungkinkan menjadi salah satu alasan mengapa tidak terdapat efek interaksi antara perlakuan dan SRL terhadap kemampuan berpikir kritis. Hal ini menjadi catatan peneliti untuk menyelidiki lebih lanjut mengapa pada penelitian dengan pembelajaran online ini tidak terdapat interaksi antara pemanfaatan antara Geogebra online berbasis scaffolding dan SRL. 


\section{SIMPULAN}

Penelitian ini menyimpulkan beberapa hal. Pertama, kemampuan berpikir kritis kelompok mahasiswa yang menggunakan Google Meet dengan Geogebra online berbasis scaffolding lebih baik dibandingkan dengan kelompok mahasiswa yang menggunakan Google Meet tanpa Geogebra online. Kedua, terdapat perbedaan kemampuan berpikir kritis mahasiswa ditinjau dari kategori SRL. Mahasiswa dengan SRL tinggi memiliki kemampuan berpikir kritis yang lebih baik daripada mahasiswa dengan SRL sedang dan rendah. Lebih lanjut mahasiswa dengan SRL sedang memiliki kemampuan berpikir kritis yang lebih baik daripada mahasiswa dengan SRL rendah. Ketiga, tidak terdapat interaksi antara jenis pembelajaran dan tingkat SRL mahasiswa terhadap kemampuan berpikir kritis. Berdasarkan temuan tersebut, disarankan kepada para pendidik untuk memanfaatkan Geogebra online berbasis scaffolding sebagai salah satu alternatif atau variasi dalam pembelajaran daring, sehingga pembelajaran diharapkan lebih interaktif dan bermakna bagi peserta didik. Selanjutnya, kepada peneliti lain disarankan untuk melakukan penelitian lanjutan yang fokus untuk menyelidiki faktor-faktor yang menyebabkan tidak adanya pengaruh interaksi antara jenis pembelajaran yang diterapkan dan kategori SRL siswa. Selain itu, penelitian juga dapat direplikasi dengan melibatkan populasi dan sampel yang lebih besar, sehingga memungkinkan generalisasi yang lebih luas.

\section{DAFTAR PUSTAKA}

Aizikovitsh, E., \& Amit, M. (2010). Evaluating an infusion approach to the teaching of critical thinking skills through mathematics. Procedia - Social and Behavioral Sciences, 2(2), 3818-3822.

https://doi.org/10.1016/j.sbspro.2010.03.596

Aizikovitsh-Udi, E., \& Amit, M. (2011). Developing the skills of critical and creative thinking by probability teaching. Procedia-Social and Behavioral Sciences, 15, 1087-1091. https://doi.org/10.1016/j.sbspro.2011.03.243

Aizikovitsh-udi, E., \& Cheng, D. (2015). Developing critical thinking skills from dispositions to abilities: Mathematics education from early childhood to high. Creative Education, 6(4), 455-462. https://doi.org/10.4236/ce.2015.64045

As'ari, A. R., Mahmudi, A., \& Nuerlaelah, E. (2017). Our prospective mathematic teachers are not critical thinkers yet. Journal on Mathematics Education, 8(2), 145-156. https://doi.org/10.22342/jme.8.2.3961.145-156

Bailin, S. (2002). Critical thinking and science education. Science and Education, 11(4), 361-375. https://doi.org/10.1023/A:1016042608621

Bakker, A., Smit, J., \& Wegerif, R. (2015). Scaffolding and dialogic teaching in mathematics education: Introduction and review. ZDM - Mathematics Education, 47(7), 1047-1065. https://doi.org/10.1007/s11858-015-0738-8

Barzilai, S., \& Blau, I. (2014). Scaffolding game-based learning: Impact on learning achievements, perceived learning, and game experiences. Computers and Education, 70, 65-79. https://doi.org/10.1016/j.compedu.2013.08.003

Bell, C. V., \& Pape, S. J. (2014). Scaffolding the development of self-regulated learning in mathematics classrooms: Results from an action research study examine the development of self-regulated learning behaviors in a seventh grade mathematics class. Middle School Journal, 45(4), 23-32. https://doi.org/10.1080/00940771.2014.11461893

Bikmaz, F. H., Çelebi, Ö., Ata, A., Özer, E., Soyak, Ö., \& Reçber, H. (2010). Scaffolding strategies applied by student teachers to teach mathematics. The International Journal of Research in Teacher Education, 1(Special Issue), 25-36. http://ijrte.eab.org.tr/media/volume1/issue3/3f.hazir.pdf

Browne, L., Hough, M., \& Schwab, K. (2009). Scaffolding: a promising approach to fostering critical thinking. SCHOLE: A Journal of Leisure Studies and Recreation Education, 24(1), 114-119. https://doi.org/10.1080/1937156x.2009.11949630

Budiyono, B. (2011). Pengantar penilaian hasil belajar. UNS Press.

Cherubini, L. (2009). Exploring prospective teachers' critical thinking: Case-based pedagogy and the standards of professional practice. Teaching and Teacher Education, 25(2), 228-234. https://doi.org/10.1016/j.tate.2008.10.007

Chukwuyenum, A. N. (2013). Impact of critical thinking on performance in mathematics among senior secondary school students in Lagos State. IOSR Journal of Research \& Method in Education, 3(5), 18-25. 
Darr, C., \& Fisher, J. (2005). Self-regulated learning in mathematics classes. Set: Research Information for Teachers, 2, 44-49. https://doi.org/10.18296/set.0631

Devolder, A., van Braak, J., \& Tondeur, J. (2012). Supporting self-regulated learning in computer-based learning environments: Systematic review of effects of scaffolding in the domain of science education. Journal of Computer Assisted Learning, 28(6), 557-573. https://doi.org/10.1111/j.1365-2729.2011.00476.x

Dikovic, L. (2009). Implementing dynamic mathematics resources with geogebra at the college level. International Journal of Emerging Technologies in Learning, 4(3), 51-54. https://doi.org/10.3991/ijet.v4i3.784

Ekawati, A. (2016). Penggunaan software geogebra dan microsoft mathematics dalam pembelajaran matematika. Math Didactic: Jurnal Pendidikan Matematika, 2(3), 148-153. https://doi.org/10.33654/math.v2i3.43

Ennis, R. H. (1985). A logical basis for measuring critical thinking skills. Educational Leadership, 43(2), 44-48.

Fong, C. J., Kim, Y., Davis, C. W., Hoang, T., \& Kim, Y. W. (2017). A meta-analysis on critical thinking and community college student achievement. Thinking Skills and Creativity, 26, 71-83. https://doi.org/10.1016/j.tsc.2017.06.002

Ghanizadeh, A. (2011). An investigation into the relationship between self-regulation and critical thinking among Iranian EFL teachers. Technology of Education, 5(3), 213-221.

http://jte.sru.ac.ir/article_292_00817d7decdf06118d88b083a2687ce9.pdf

Hidayati, D. W., \& Kurniati, L. (2018). The influence of self regulated learning to mathematics critical thinking ability on 3D-shapes geometry learning using geogebra. JIPM (Jurnal IImiah Pendidikan Matematika), 7(1), 40-48. https://doi.org/10.25273/jipm.v7i1.2965

Incikabi, L., Tuna, A., \& Biber, A. C. (2013). An analysis of mathematics teacher candidates' critical thinking dispositions and their logical thinking skills. Journal of International Education Research, 9(3), 257-267. https://doi.org/10.19030/jier.v9i3.7884

Jacob, S. M. (2012). Mathematical achievement and critical thinking skills in asynchronous discussion forums. Procedia-Social and Behavioral Sciences, 31, 800-804. https://doi.org/10.1016/j.sbspro.2011.12.144

Kim, K., Sharma, P., Land, S. M., \& Furlong, K. P. (2013). Effects of active learning on enhancing student critical thinking in an undergraduate general science course. Innovative Higher Education, 38(3), 223-235. https://doi.org/10.1007/s10755-012-9236-x

Kramarski, B., \& Revach, T. (2009). The challenge of self-regulated learning in mathematics teachers' professional training. Educational Studies in Mathematics, 72(3), 379-399. https://doi.org/10.1007/s10649-009-9204-2

Kurniasih, A. W. (2012). Scaffolding sebagai alternatif upaya meningkatkan kemampuan berpikir kritis matematika. Kreano: Jurnal Matematika Kreatif-Inovatif, 3(2), 113-124. https://doi.org/10.15294/kreano.v3i2.2871

Maričić, S., \& Špijunović, K. (2015). Developing critical thinking in elementary mathematics education through a suitable selection of content and overall student performance. Procedia-Social and Behavioral Sciences, 180, 653-659. https://doi.org/10.1016/j.sbspro.2015.02.174

Miatun, A., \& Khusna, H. (2020). Kemampuan berpikir kritis matematis berdasarkan disposisi matematis. AKSIOMA: Jurnal Program Studi Pendidikan Matematika, 9(2), 269-278. https://doi.org/10.1017/CBO9781107415324.004

Moschkovich, J. N. (2015). Scaffolding student participation in mathematical practices. ZDM - Mathematics Education, 47(7), 1067-1078. https://doi.org/10.1007/s11858-015-0730-3

Nursyahidah, F., \& Albab, I. U. (2018). Identifikasi kemampuan berpikir kritis matematis mahasiswa berkemampuan pemecahan masalah level rendah dalam pembelajaran kalkulus integral berbasis problem based learning. Jurnal Elemen, 4(1), 34-49. https://doi.org/10.29408/jel.v4i1.513

OECD. (2019). PISA 2018 results (Volume I): What students know and can do. OECD Publishing. https://doi.org/10.1787/5f07c754-en 
Perry, N. E., Hutchinson, L., \& Thauberger, C. (2008). Talking about teaching self-regulated learning: Scaffolding student teachers' development and use of practices that promote self-regulated learning. International Journal of Educational Research, 37(2), 97-108. https://doi.org/10.1016/j.ijer.2007.11.010

Peter, E. E. (2012). Critical thinking: Essence for teaching mathematics and mathematics problem solving skills. African Journal of Mathematics and Computer Science Research, 5(3), 39-43. https://doi.org/10.5897/ajmcsr11.161

Qohar, A., \& Sumarmo, U. (2013). Improving mathematical communication ability and self regulation learning of yunior high students by using reciprocal teaching. Journal on Mathematics Education, 4(1), 59-74. https://doi.org/10.22342/jme.4.1.562.59-74

Quitadamo, I. J., Brahler, C. J., \& Crouch, G. J. (2009). Peer-led team learning: A prospective method for increasing critical thinking in undergraduate science courses. Sciences Educator, 18(1), 29-39.

Riyadhotul, S., Suyitno, H., \& Rosyida, I. (2019). Pentingnya literasi matematika dan berpikir kritis matematis dalam menghadapi abad ke-21. PRISMA: Prosiding Seminar Nasional Matematika, 2, 905-910. https://journal.unnes.ac.id/sju/index.php/prisma/article/download/29305/12924

Rochmad, R., Kharis, M., \& Agoestanto, A. (2018). Keterkaitan miskonsepsi dan berpikir kritis aljabaris mahasiswa S1 pendidikan matematika. PRISMA, Prosiding Seminar Nasional Matematika, 1, 216-224. https://journal.unnes.ac.id/sju/index.php/prisma/article/view/19577

Shadaan, P., \& Eu, L. K. (2013). Effectiveness of using geogebra on students' understanding in learning circles. Malaysia Online Journal of Educational Technology, 1(4), 1-11. http://www.mojet.net/articles/pdf/v01i04/v01i04-01.pdf

Shih, K. P., Chen, H. C., Chang, C. Y., \& Kao, T. C. (2010). The development and implementation of scaffolding-based self-regulated learning system for e/m-learning. Educational Technology and Society, 13(1), 80-93. https://doi.org/10.1109/ITRE.2005.1503060

Smit, J., Van Eerde, H. A. A., \& Bakker, A. (2013). A conceptualisation of whole-class scaffolding. British Educational Research Journal, 39(5), 817-834. https://doi.org/10.1002/berj.3007

Sulistiani, E., \& Masrukan, M. (2017). Pentingnya berpikir kritis dalam pembelajaran matematika untuk menghadapi tantangan MEA PRISMA: Prosiding Seminar Nasional Matematika, 605-612. https://journal.unnes.ac.id/sju/index.php/prisma/article/view/21554

Sumarmo, U. (2002). Kemandirian belajar: Apa, mengapa, dan bagaimana dikembangkan pada peserta didik. Makalah Disajikan pada Seminar Nasional FMIPA UNY 2002.

Sunaryo, Y., \& Fatimah, A. T. (2019). Pendekatan kontekstual dengan scaffolding untuk meningkatkan kemampuan berpikir kritis matematis. JNPM (Jurnal Nasional Pendidikan Matematika), 3(1), 66-79. https://doi.org/10.33603/jnpm.v3i1.1468

Susilo, B. E., Darhim, D., \& Prabawanto, S. (2019). Students critical thinking skills toward concepts differences in finding area of a plane region and definite integral. Unnes Journal of Mathematics Education, 8(1), 1-7. https://doi.org/10.15294/ujme.v8i1.29463

Terenzini, P. T., Springer, L., Pascarella, E. T., \& Nora, A. (1995). Influences affecting the development of students' critical thinking skills. Research in Higher Education, 36(1), 23-39. https://doi.org/10.1007/BF02207765

Velichová, D. (2011). Interactive maths with geogebra. International Journal of Emerging Technologies in Learning, 6(Special Issue.2), 31-35. https://doi.org/10.3991/ijet.v6iS1.1620

Vong, S. A., \& Kaewurai, W. (2017). Instructional model development to enhance critical thinking and critical thinking teaching ability of trainee students at regional teaching training center in Takeo province, Cambodia. Kasetsart Journal of Social Sciences, 38(1), 88-95. https://doi.org/10.1016/j.kjss.2016.05.002

Vrieling, E., Stijnen, S., \& Bastiaens, T. (2018). Successful learning: Balancing self-regulation with instructional planning. Teaching in Higher Education, 23(6), 685-700. https://doi.org/10.1080/13562517.2017.1414784 
PYTHAGORAS: Jurnal Pendidikan Matematika, 15 (2), 2020 - 136

Asih Miatun, Hikmatul Khusna

Zengin, Y. (2017). The effects of geogebra software on pre-service mathematics teachers' attitudes and views toward proof and proving. International Journal of Mathematical Education in Science and Technology, 48(7), 1002-1022. https://doi.org/10.1080/0020739X.2017.1298855

Zimmerman, B. J., \& Martinez-Pons, M. (1988). Construct validation of a strategy model of student self-regulated learning. Journal of Educational Psychology, 80(3), 284-290. https://doi.org/10.1037//0022-0663.80.3.284

Zimmerman, B. J., \& Martinez-Pons, M. (1990). Student differences in self-regulated learning: Relating grade, sex, and giftedness to self-efficacy and strategy use. Journal of Educational Psychology, 82(1), 51-59. https://doi.org/10.1037/0022-0663.82.1.51

Zumbrunn, S., Tadlock, J., \& Roberts, E. D. (2011). Encourage self regulated learning in the classroom. Metropolitan Educational Research Consortium (MERC), Virginia Commonwealth University.

http://scholarscompass.vcu.edu/merc_pubs/18 